\title{
Atividade pozolânica de adições minerais para cimento Portland (Parte I): Índice de atividade pozolânica (IAP) com cal, difração de raios-X (DRX), termogravimetria (TG/DTG) e Chapelle modificado
}

\author{
Pozzolanic activity of mineral additions to Portland cement \\ (Part I): Pozzolanic activity index with lime (PAI), X-ray \\ diffraction (XRD), thermogravimetry (TG/DTG) and \\ modified Chapelle
}

\author{
Juarez Hoppe Filho ${ }^{1}$, Andressa Gobbi ${ }^{2}$, Eduardo Pereira ${ }^{3}$, \\ Valdecir Angelo Quarcioni ${ }^{4}$, Marcelo Henrique Farias de Medeiros ${ }^{5}$
}

\footnotetext{
${ }^{1}$ Centro das Ciências Exatas e das Tecnologias, Universidade Federal do Oeste da Bahia, Barreiras, BA e-mail: juarez.hoppe@gmail.com

${ }^{2}$ Departamento de Construção Civil, Universidade Federal do Paraná, Curitiba, PR

e-mail: andressagobbi@yahoo.com.br

${ }^{3}$ Departamento de Engenharia Civil, Universidade Estadual de Ponta Grossa, Ponta Grossa, PR

e-mail: eduardopereira@uepg.br

${ }^{4}$ Laboratório de Materiais de Construção Civil, Instituto de Pesquisas Tecnológicas do Estado de São Paulo - IPT

e-mail: quarciva@ipt.br

${ }^{5}$ Departamento de Construção Civil, Universidade Federal do Paraná, Curitiba, PR

e-mail: medeiros.ufpr@gmail.com
}

\section{RESUMO}

A seleção de adição mineral pozolânica para compor a matriz de cimento Portland requer determinação prévia de sua reatividade, o que é realizado diretamente, por meio do ensaio Chapelle modificado (NBR 15.895), ou indiretamente, pelo ensaio de resistência à compressão de argamassa com cal (NBR 5.751). O teor de hidróxido de cálcio fixado pela pozolana e, consequentemente, os compostos hidratados formados, são subsídios na avaliação e discussão dos métodos normativos utilizados para caracterizar a atividade pozolânica. A determinação do teor de cal fixado requer, impreterivelmente, disponibilidade alcalina no sistema durante o período de ensaio estabelecido nas normas técnicas. O esgotamento precoce da cal invalida a determinação do teor de hidróxido de cálcio fixado, interfere na resistência à compressão da argamassa e, por fim, subestima a reatividade da pozolana. O presente trabalho aborda a avaliação da atividade pozolânica de sistemas hidróxido de cálcio - adição mineral, a partir dos métodos prescritos nas normas brasileiras pertinentes, e a análise complementar ao método indireto, baseado na resistência à compressão de argamassa com cal, por meio de difratometria de raios-X (DRX) e termogravimetria (TG/DTG) aplicadas em pastas em proporções de mistura idênticas às contidas nas argamassas. A análise conjunta do índice de atividade pozolânica (IAP) com DRX e TG/DTG visa analisar o consumo/esgotamento de portlandita nos sistemas e demonstrar que algumas pozolanas apresentam baixo desempenho quando avaliadas pela resistência à compressão de argamassas com cal, mesmo se capazes de fixar elevado teor de hidróxido de cálcio para formar compostos hidratados. Assim sendo, o método indireto, conforme a NBR 5.751, não é adequado para hierarquizar pozolanas de alta reatividade, como a sílica ativa e o metacaulim.

Palavras-chave: adições minerais, atividade pozolânica, resistência à compressão, ensaio Chapelle modificado.

\footnotetext{
ABSTRACT

Selecting of pozzolanic mineral additions to compose Portland cement requires previous determination of their reactivity. This is defined directly by the modified Chapelle test (NBR 15.895), or indirectly, by compressive strength test of lime mortar (NBR 5.751). The calcium hydroxide content consumed by pozzolan and formed hydrated compounds, are parameters in the evaluation and discussion of the standard methods used to characterize the pozzolanic activity. Determination of the lime content consumed requires, in any
} 
case, alkaline availability in the system during the test period established by the standard methods. The early consumption of lime invalidates the determination of fixed calcium hydroxide content, interferes in the compressive strength of the mortar, and finally, underestimates the reactivity of the pozzolan. This paper evaluates the pozzolanic activity of calcium hydroxide + mineral additions system, from standard methods in Brazil, and further analysis based on compression strength with lime mortar, X-ray diffraction (XRD) and thermogravimetry (TG / DTG) applied in paste of mixing ratios identical to those contained in the mortar. The combined analysis of the pozzolanic activity index (IAP) with XRD and TG / DTG aims to analyze the consumption of portlandite in the systems and demonstrate that some pozzolans have low performance when evaluated by the compressive strength. This performance is found even if pozzolans are able to consume high calcium hydroxide content to form hydrated compounds. Therefore, the indirect method, according to NBR 5.751 , is not suitable to rank high reactivity pozzolans such as silica fume and metakaolin.

Keywords: mineral additions, pozzolanic activity, compressive strength, modified Chapelle test.

\section{INTRODUÇÃO}

Adições pozolânicas podem ser incorporadas ao cimento Portland durante a produção originando os cimentos do tipo CP II Z ou CP V ou ainda serem adicionadas as misturas durante a produção de concretos e argamassas. A incorporação de adições minerais à composição do cimento Portland é, atualmente, indispensável para a indústria cimenteira, haja vista as vantagens econômicas e ambientais propiciadas. A redução no consumo de clínquer e a adequada destinação de resíduos industriais justificam a crescente utilização das adições minerais, pois insere o cimento Portland nos preceitos da sustentabilidade e fomenta a mitigação do passivo ambiental das empresas geradoras de resíduos [1-2].

No âmbito técnico-científico, as adições minerais ativas exercem influência sobre a cinética de hidratação do cimento Portland e, por atividade química, formam produtos hidratados secundários. Como consequência, a microestrutura da matriz hidratada é alterada, principalmente no que se refere ao refinamento dos poros, o que incrementa, na maioria das vezes, a durabilidade das obras civis executadas com estes materiais ligantes [1].

A produção nacional de cimento Portland, em 2013, foi de 70,2 milhões de toneladas, representada, em $86 \%$, pelos tipos CP II, CP III e CP IV [3], os quais contêm adições minerais ativas e inertes em diferentes teores. No Brasil, as adições minerais ativas normalmente incorporadas à composição do cimento são a cinza volante, a argila calcinada e a escória granulada de alto forno, sendo o fíler calcário utilizado como adição inerte. $\mathrm{O}$ grande volume de adições minerais ativas incorporado à composição do cimento Portland evidencia a importância da caracterização, seleção e entendimento da cinética de reação destes materiais na presença de portlandita, além dos efeitos sobre a hidratação do próprio cimento.

A caracterização das adições minerais ativas do tipo pozolana está baseada, na prática, em métodos indiretos de quantificação do potencial reativo, por meio do índice de atividade pozolânica (IAP) com cimento Portland ou cal hidratada, conforme preconizam as normas NBR 5.752 [4] e NBR 5.751 [5], respectivamente. Com o método direto, denominado ensaio Chapelle modificado [6], determina-se a capacidade da adição pozolânica em fixar cal para a formação de compostos hidratados que, apesar de mais criterioso em comparação aos métodos indiretos, é de realização restrita a centros especializados.

Os diferentes métodos normatizados de quantificação do potencial reativo, apesar das limitações, são capazes de subsidiar a seleção das adições minerais pozolânicas normalmente utilizadas, porém podem subestimar a reatividade de super pozolanas, como a sílica de casca de $\operatorname{arroz}^{1}$, a sílica ativa e o metacaulim. A alta reatividade destas pozolanas, decorrente do alto teor de amorfos e, sobretudo, da elevada área específica, conduz a um elevado consumo de portlandita que, nas argamassas de cimento Portland ou cal hidratada, preconizadas pelas respectivas normas brasileiras para determinação do IAP, podem esgotar a reserva alcalina do meio, sobretudo em condição de reação acelerada pela cura térmica.

A literatura apresenta resultados controversos para a pozolanicidade quando as adições minerais são avaliadas por diferentes métodos indiretos. Gava e Prudêncio Jr. [7], ao avaliarem o IAP da cinza volante, cinza de casca de arroz e sílica ativa, conforme as metodologias propostas pelas normas ABNT NBR 5.752/1992, ASTM C311/1993, ASTM C1240²/1993 e BS EN 4503/1995, evidenciaram que alguns métodos restringem o uso de determinada adição como pozolana por não cumprir os requisitos normativos, além de

\footnotetext{
${ }^{1}$ Sílica de casca de arroz: material obtido a partir da queima da casca de arroz em leito fluidizado com controle de temperatura.

${ }^{2}$ Metodologia recomendada exclusivamente para sílica ativa.

${ }^{3}$ Metodologia recomendada exclusivamente para cinza volante.
} 
observarem variação de resultados, para as mesmas adições, quando aplicados os procedimentos de ensaio preconizados nas normas, sobretudo em decorrência das diferentes temperaturas de cura. Os autores também salientam que os métodos não consideram a área específica da adição e a relação água/ligantes constante ${ }^{4}, \mathrm{o}$ que propicia à adição com elevada área específica, mais reativa, redução no desempenho em virtude da maior demanda de água de mistura para cumprir a exigência normativa referente à consistência. Os mesmos autores, Gava e Prudêncio Jr. [8], ainda concluíram que outros fatores exercem influência no IAP, tais como: procedência e características físico-químicas do cimento, teor de substituição do cimento por adição pozolânica, uso de aditivos dispersantes e, principalmente, a temperatura de cura. Por fim, ressaltam que o desempenho das pozolanas em argamassa e concreto não está, obrigatoriamente, relacionado ao desempenho obtido nos ensaios de avaliação da atividade pozolânica normatizados pela Associação Brasileira de Normas Técnicas $(\mathrm{ABNT})$ e pelas normas internacionais vigentes à época $\left(\mathrm{ASTM}^{5} \mathrm{e} \mathrm{BS}^{6}\right)$.

Diante dos inúmeros fatores intervenientes, Donatello et al. [9] sugerem que, ao avaliar a atividade pozolânica de um material, é importante escolher o método baseado nas condições e particularidades de ensaio e, sobretudo, com ciência das limitações da metodologia. Assim sendo, recomendam a avaliação por mais de um método, independentemente de haver correlação entre os mesmos, desde que um deles quantifique o consumo de portlandita ao longo do tempo. No que se refere à análise comparativa dos resultados, há que se enfatizar o tempo de exposição da amostra à temperatura de cura para cada método de ensaio.

Deschner et al. [10] demonstram que o aumento da temperatura de cura de sistemas cimentícios pozolânicos propicia maior consumo de cal por atividade pozolânica, com consequente incremento de propriedades mecânicas das pastas. Por outro lado, o consumo de cal também está relacionado com o tamanho das partículas da pozolana, em decorrência da área específica [11-12], o que propicia variada interação da superfície dos grãos com o meio alcalino responsável pela solubilização da matriz amorfa.

Zerbino et al. [13] destacam a importância da distribuição granulométrica da cinza de casca de arroz no que tange ao desempenho da pasta que a incorpora. O concreto contendo cinza de casca de arroz, em teor de substituição de $15 \%$ em massa, apresenta melhorias nas propriedades do estado fresco e, também, nas propriedades mecânicas e na durabilidade em função da maior finura da pozolana. $\mathrm{O}$ tamanho das partículas, conforme Zerbino et al. [14], pode, inclusive, influenciar na inibição ou desenvolvimento da reação álcalisílica (RAS). A mitigação ou exacerbação da RAS depende do teor de substituição do cimento e, preponderantemente, do tamanho das partículas da pozolana.

De fato, a atividade pozolânica é influenciada por inúmeros fatores, dentre os quais ainda podem ser citados a relação portlandita/pozolana, $\mathrm{pH}$ do meio, teor de fase amorfa contido na adição mineral e composição da matriz amorfa [1]. Portanto, a mensuração da pozolanicidade de um material é bastante complexa, sendo necessário dispor de metodologias para subsidiar a hierarquização de adições minerais a serem incorporadas no cimento Portland. No Brasil, as metodologias, sejam diretas ou indiretas, estão embasadas na reação da adição mineral com cal hidratada, conforme as normas NBR 15.895 [6] e NBR 5.751 [5], ou com cimento Portland, conforme a norma NBR 5.752 [4].

A classificação, segundo as normas, está fundamentada na resistência à compressão da argamassa pozolânica ou na fixação de cal em um intervalo de tempo pré-estabelecido, sem qualquer menção referente à análise do consumo de portlandita ao longo do tempo. Assim sendo, este trabalho, dividido em duas partes, pretende ampliar a análise acerca da pozolanicidade das adições minerais, incluindo a difratometria de raios$\mathrm{X}$ e a termogravimetria como técnicas complementares para verificação da compatibilidade da avaliação da atividade pozolânica de adições minerais de alta reatividade com as metodologias propostas nas normas NBR 5.751 [5] e NBR 5.752 [4].

A primeira parte do trabalho objetiva avaliar a adequabilidade das metodologias propostas nas normas brasileiras, embasadas na determinação da atividade pozolânica com cal hidratada, para a classificação/hierarquização de adições minerais de alta reatividade, como a sílica de casca de arroz, a sílica ativa e o metacaulim. A segunda parte, objeto de publicação posterior, contempla a mesma análise, porém com base na determinação da atividade pozolânica com cimento Portland. Em ambos os casos, é importante ressaltar que a ABNT preconiza ensaios com normas específicas para a classificação da sílica ativa e do metacaulim, que são opções classicamente disponíveis no mercado nacional. Porém, este trabalho tem o foco de testar se um único procedimento poderia ser adotado para a classificação de pozolanas (o da NBR 5.751 [5] ou o da NBR 5.752 [4]) e, se isso não é possível, produzir uma análise crítica identificando as causas desta impossibilidade. Além disso, deve-se ressaltar que a sílica ativa e o metacaulim não são as únicas adições de alta reati-

\footnotetext{
${ }_{5}^{4}$ A norma BS EM 450/1995 considera a relação água/ligantes constante.

5 ASTM: American Society for Testing and Materials.

${ }^{6}$ BS: British Standard.
} 
vidade pozolânica, existindo neste trabalho o exemplo da cinza de casca de arroz que se testada no Brasil teria que ser submetida aos procedimentos da NBR 5.751 [5] e da NBR 5.752 [4], mesmo sendo uma pozolana de alta reatividade.

\section{MATERIAIS E MÉTODOS}

\subsection{Materiais}

\subsubsection{Adições minerais}

As adições minerais pozolânicas utilizadas foram a sílica de casca de arroz, a sílica ativa e o metacaulim e, como adições inertes, o fíler calcário e o fíler quartzoso (pó de quartzo). A utilização de adições inertes visa, única e exclusivamente, demonstrar que a metodologia proposta nas normas pertinentes impossibilita classificar de forma equivocada as adições não reativas.

A sílica de casca de arroz é assim denominada por ser obtida a partir da queima controlada em leito fluidizado, o que acarreta alto teor de amorfos e baixo teor de carbono residual (perda ao fogo máxima de $3,00 \%)$ na sua composição.

A Tabela 1 apresenta os resultados da análise química das adições minerais por fluorescência de raios$\mathrm{X}$. Cabe ressaltar que o fíler calcário é, de fato, dolomítico, em virtude do teor de $15 \%$ de óxido de magnésio presente na sua composição.

Tabela 1: Análise química por fluorescência de raios-X das adições minerais.

\begin{tabular}{|c|c|c|c|c|c|c|c|c|}
\hline & \multirow{2}{*}{ Adições minerais } & \multicolumn{7}{|c|}{ Composição química (\%) } \\
\hline & & $\mathrm{SiO}_{2}$ & $\mathbf{A l}_{2} \mathbf{O}_{3}$ & $\mathrm{Fe}_{2} \mathrm{O}_{3}$ & $\mathrm{CaO}$ & $\mathbf{K}_{2} \mathbf{O}$ & $\mathrm{SO}_{3}$ & MgO \\
\hline \multirow{3}{*}{ Ativas } & Sílica de casca de arroz & 92,97 & 2,86 & 0,05 & 0,45 & 1,53 & 1,63 & --- \\
\hline & Sílica ativa & 94,91 & 2,27 & 0,05 & 0,20 & 0,97 & 1,56 & --- \\
\hline & Metacaulim & 42,36 & 52,96 & 1,79 & 0,07 & --- & 1,50 & --- \\
\hline \multirow{2}{*}{ Inertes } & Fíler calcário & 2,97 & 1,73 & 0,44 & 78,03 & 0,31 & 1,21 & 15,06 \\
\hline & Fíler quartzoso & 95,79 & 2,88 & --- & --- & --- & 1,27 & --- \\
\hline
\end{tabular}

As adições minerais inertes, conforme os difratogramas apresentados na Figura 1, não possuem halo amorfo e, portanto, não são passíveis de interação com o hidróxido de cálcio. O fíler calcário é constituído por calcita $\left(\mathrm{CaCO}_{3}\right)$, dolomita $\left(\mathrm{CaCO}_{3} \cdot \mathrm{MgCO}_{3}\right)$ e quartzo, enquanto o fíler quartzoso contém apenas quartzo em sua composição.
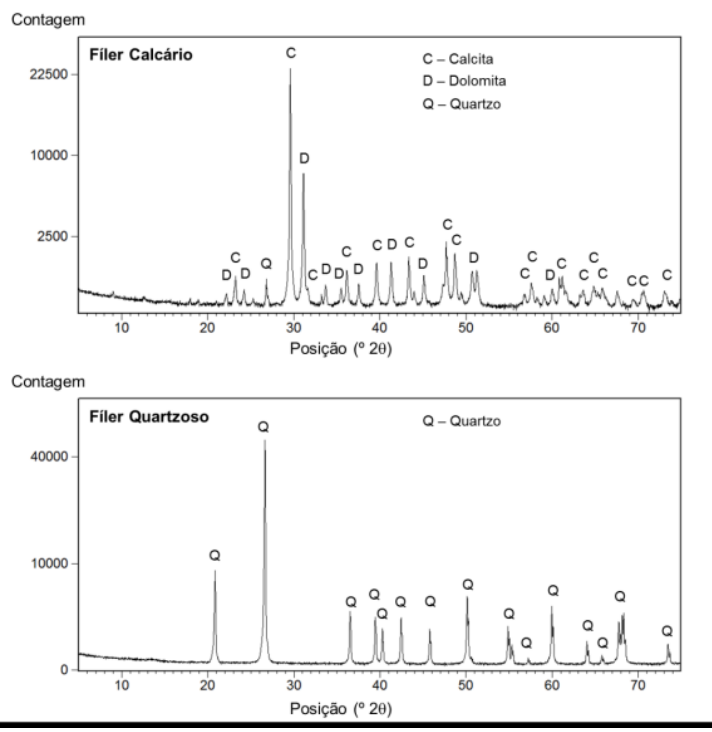

Figura 1: Difratogramas das adições minerais inertes. 
Os difratogramas das adições minerais pozolânicas são apresentados na Figura 2. A banda difusa, presente em todos os difratogramas, caracteriza a existência de estrutura amorfa, passível de atividade pozolânica.

Na sílica de casca de arroz há identificação de picos referentes à cristobalita, uma das formas polimórficas do dióxido de silício $\left(\mathrm{SiO}_{2}\right)$. A sílica ativa não apresenta qualquer pico no difratograma, portanto, tratase de um material completamente amorfo. Já o metacaulim contém, além da matriz amorfa, picos característicos de caulinita $\left(\mathrm{Al}_{2} \mathrm{Si}_{2} \mathrm{O}_{5}(\mathrm{OH})_{4}\right)$, muscovita $\left(\mathrm{Al}_{3} \mathrm{H}_{2} \mathrm{KO}_{12} \mathrm{Si}_{3}\right)$ e quartzo.

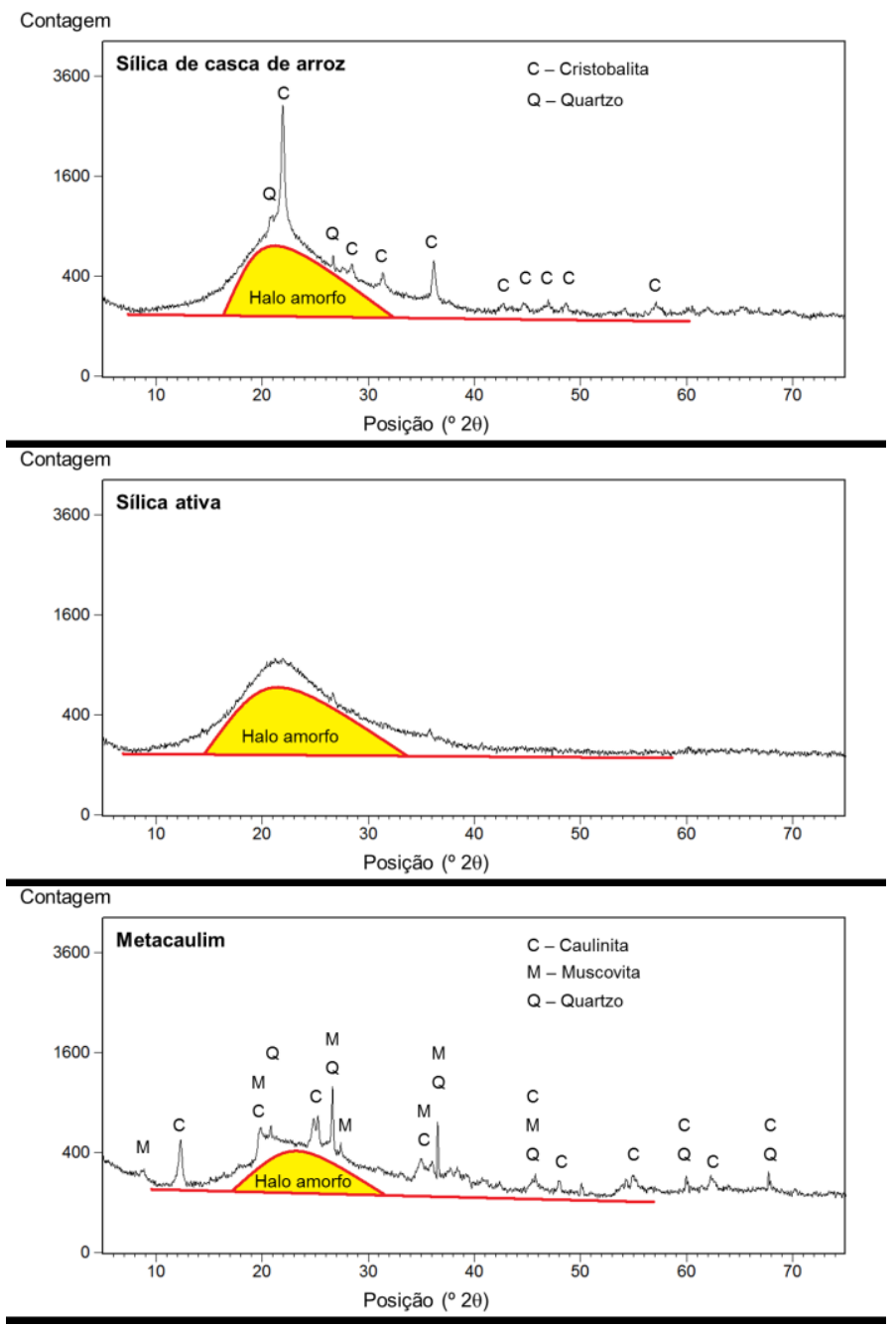

Figura 2: Difratogramas das adições minerais pozolânicas.

As características físicas das adições minerais são apresentadas na Tabela 2. A área específica BET das adições ativas é significativamente superior à área das adições inertes, o que não se verifica por análise da área específica Blaine.

Tabela 2: Características físicas das adições minerais.

\begin{tabular}{|c|c|c|c|c|}
\hline \multirow{2}{*}{\multicolumn{2}{|c|}{ Adições minerais }} & Massa específica & Área específica BLAINE & Área específica BET \\
\hline & & $\left(\mathrm{g} / \mathrm{cm}^{3}\right)$ & $\left(\mathrm{m}^{2} / \mathrm{g}\right)$ & $\left(\mathrm{m}^{2} / \mathrm{g}\right)$ \\
\hline \multirow{3}{*}{ Ativas } & Sílica de casca de arroz & 2,12 & 0,70 & 14,69 \\
\hline & Sílica ativa & 2,18 & 0,72 & 20,24 \\
\hline & Metacaulim & 2,50 & 0,47 & 23,26 \\
\hline \multirow{2}{*}{ Inertes } & Fíler calcário & 2,70 & 0,76 & 1,41 \\
\hline & Fíler quartzoso & 2,60 & 0,80 & 1,23 \\
\hline
\end{tabular}


Quarcioni [15], ao obter a área específica para o cimento CP II E de $0,39 \mathrm{~m}^{2} / \mathrm{g}$ pelo método Blaine e $1,10 \mathrm{~m}^{2} / \mathrm{g}$ pelo método BET, indica que a área específica Blaine é obtida a partir de um fluxo contínuo de ar, limitando-se à superfície externa das partículas, enquanto o método BET mede também a superfície interna dos poros abertos e interconectados. Portanto, a área específica BET é mais fidedigna para se inferir a disponibilidade de área das partículas para a interação com as espécies químicas presentes no meio aquoso.

As curvas de distribuição granulométrica a laser das adições minerais e, também, do hidróxido de cálcio p.a. estão apresentadas na Figura 3. A sílica de casca de arroz e o fíler quartozoso são as adições que possuem maior percentual de partículas com dimensão inferior a $10 \mu \mathrm{m}$. No geral, a sílica de casca de arroz apresenta a maior finura dentre as adições, enquanto o fíler calcário apresenta a menor finura.
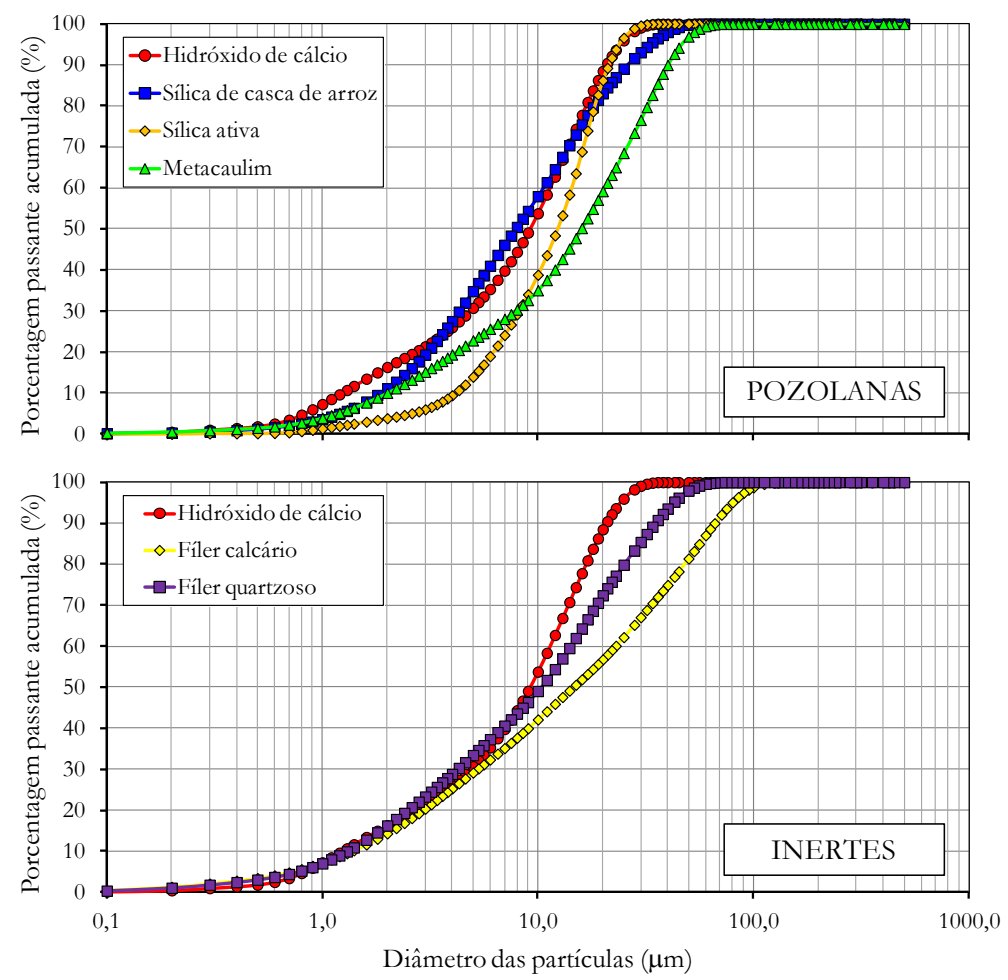

Figura 3: Distribuição granulométrica a laser do hidróxido de cálcio e das adições minerais.

\subsubsection{Hidróxido de cálcio}

O hidróxido de cálcio, com massa específica de $2,24 \mathrm{~g} / \mathrm{cm}^{3}$, foi caracterizado por análise térmica (TG/DTG) usando o equipamento da marca TA Instruments, modelo 2960 SDT, utilizando o nitrogênio grau analítico $\left(100 \mathrm{~mL} /\right.$ minuto) como purga dos gases volatilizados. A taxa de aquecimento foi de $10{ }^{\circ} \mathrm{C} /$ minuto entre $35^{\circ} \mathrm{C}$ e $1.000{ }^{\circ} \mathrm{C}$, em cadinho de alumina sem tampa. O reagente químico contém aproximadamente $1,09 \%$ de água que foi completamente volatilizada até $325^{\circ} \mathrm{C}$ e $5,56 \%$ de carbonato de cálcio. $\mathrm{O}$ hidróxido de cálcio representa $88,78 \%$ da massa do material.

\subsection{Argamassas - Índice de atividade pozolânica com cal (NBR 5.751)}

A determinação do IAP com cal requer que a argamassa a ser avaliada contenha uma determinada massa de hidróxido de cálcio e uma quantidade de adição mineral que corresponda ao dobro do volume do reagente grau analítico. Além desta premissa, a argamassa a ser submetida ao ensaio de resistência à compressão deve apresentar, no estado fresco, um índice de consistência pré-estabelecido $(225 \pm 5 \mathrm{~mm})^{7}$, o que conduz a variados volumes de água de mistura em função das características físico-químicas das adições minerais avaliadas.

A Tabela 3 apresenta as proporções de mistura das argamassas e a relação portlandita/adição mineral,

7 Índice de consistência obtido no ensaio de abatimento, conforme prescreve a ABNT NBR $7.215 / 1997$. 
sendo possível observar a variação da relação água/ligantes em função das características físico-químicas das adições minerais.

Tabela 3: Proporção de mistura das argamassas, relação água/ligantes e relação portlandita/adição mineral.

\begin{tabular}{|c|c|c|c|c|c|c|c|}
\hline \multirow{2}{*}{\multicolumn{2}{|c|}{ Adições minerais }} & \multicolumn{4}{|c|}{ Massa dos materiais (g) } & \multirow{2}{*}{$\begin{array}{c}\text { Relação } \\
\text { Água/Ligantes } \\
\text { (g/g) }\end{array}$} & \multirow{2}{*}{$\begin{array}{c}\text { Relação } \\
\text { CH/Adição }{ }^{3} \\
\text { (g/g) }\end{array}$} \\
\hline & & Hidróxido & Areia & Adição & Áoua & & \\
\hline \multirow{3}{*}{ Ativas } & Sílica de casca de arroz & \multirow{5}{*}{104,0} & \multirow{5}{*}{936,0} & 196,9 & 200,0 & 0,66 & 0,47 \\
\hline & Sílica ativa & & & 202,4 & 340,0 & 1,11 & 0,46 \\
\hline & Metacaulim & & & 232,1 & 270,0 & 0,80 & 0,40 \\
\hline \multirow{2}{*}{ Inertes } & Fíler calcário & & & 250,7 & 180,0 & 0,51 & 0,37 \\
\hline & Fíler quartzoso & & & 241,4 & 200,0 & 0,58 & 0,38 \\
\hline
\end{tabular}

${ }^{1}$ Areia normal brasileira (NBR 7.214): 234 gramas de cada fração granulométrica.

${ }^{2}$ Relação água/ligantes: quociente entre a massa de água e a soma das massas de hidróxido de cálcio e adição mineral contidas na argamassa - água/ (hidróxido de cálcio + adição mineral).

${ }^{3}$ Relação hidróxido de cálcio/adição: quociente entre as massas de hidróxido de cálcio e adição mineral contidas na argamassa. A massa efetiva de hidróxido de cálcio é de 92,3 gramas (104 g x 88,78\%).

\subsection{Pastas com hidróxido de cálcio para difração de raios-X e termogravimetria}

As pastas moldadas para a quantificação do consumo de cal por atividade pozolânica seguiram as recomendações da NBR 5.751 [5], ou seja, o volume de adição mineral é o dobro do volume empregado de hidróxido de cálcio p.a.. A relação água/ligantes (hidróxido de cálcio + adição mineral) foi mantida constante em 0,80 , de forma a permitir a adequada mistura das pastas com sílica ativa e metacaulim, as quais demandam maior volume de água em decorrência das suas características físico-químicas. Após a mistura, as pastas foram lançadas em sacos plásticos $( \pm 25 \mathrm{~mL}$ ) e acondicionadas em recipientes poliméricos de $50 \mathrm{~mL}$, com tampa, objetivando minimizar a evaporação de água durante a cura térmica, a $(55 \pm 2)^{\circ} \mathrm{C}$ durante 6 dias, após 1 dia de cura à temperatura de $(23 \pm 2)^{\circ} \mathrm{C}$.

\subsubsection{Preparo das amostras para difração de raios-X (DRX) e termogravimetria (TG/DTG)}

As amostras das diferentes pastas com cal hidratada, aos 7 dias de idade, foram retiradas da estufa à $55^{\circ} \mathrm{C}$, fragmentadas em pedaços com dimensão máxima de 5,0 $\mathrm{mm}$ (aproximadamente), acondicionadas em recipientes poliméricos com tampa e congeladas/estocadas em freezer à $-30^{\circ} \mathrm{C}$ para paralisar as reações de hidratação. Na sequência, alguns fragmentos das amostras (volume necessário para a realização da DRX e TG/DTG) foram liofilizados em Liofilizador Terroni LS 3000 para sublimar a água livre, restando, nas amostras, apenas a água quimicamente combinada e parte da água adsorvida na estrutura dos compostos hidratados formados.

As amostras liofilizadas foram finamente moídas em almofariz cerâmico com pistilo, acondicionadas em tubos tipo Eppendorf $(2 \mathrm{~mL})$ e estocadas em dessecador contendo sílica gel até a realização dos ensaios.

O preparo das amostras para a coleta dos difratogramas foi realizado por prensagem manual no portaamostra, seguido de exposição aos raios-X no difratômetro RIGAKU modelo Ultima IV. A análise foi realizada entre $5^{\circ}$ e $75^{\circ} 2 \theta$, com passo angular de $0,02^{\circ} 2 \theta$ e tempo por passo de 1 segundo. Na coleta se utilizou tubo com ânodo de cobre, $40 \mathrm{kV} / 30 \mathrm{~mA}$ e fenda divergente de $1^{\circ}$.

O ensaio de termogravimetria foi realizado conforme descrito no item 2.1.2, utilizando uma massa média de amostra de $10 \mathrm{mg}$.

\subsection{Ensaio Chapelle modificado}

A capacidade da adição mineral em fixar cal, por ação pozolânica, para a formação de compostos hidratados em ensaio acelerado, é determinada por meio do método prescrito na NBR 15.895 [6]. O ensaio consiste, basicamente, em manter sob agitação, por um período de $16 \pm 2$ horas, à temperatura de $(90 \pm 5){ }^{\circ} \mathrm{C}$, uma mistura de 1,0 (um) grama de adição mineral e 2,0 (dois) gramas de óxido de cálcio $(\mathrm{CaO}) \mathrm{em} 250 \mathrm{~mL}$ de água, acondicionada em Erlenmeyer polimérico. O resultado, obtido por titulação, é expresso pela quantidade 
de hidróxido de cálcio fixado por grama de adição mineral.

\section{ANÁLISE E DISCUSSÃO DOS RESULTADOS}

\section{1 Índice de atividade pozolânica com cal (NBR 5.751)}

O potencial reativo das adições minerais, obtido pelo método indireto normatizado, está baseado na determinação da carga de ruptura à compressão de corpos de prova moldados com proporção de mistura volumétrica dos materiais particulados fixa e volume de água variável, já que as argamassas, no estado fresco, devem apresentar um índice de consistência pré-estabelecido. As condições impositivas preconizadas pela norma NBR 5.751 [5] interferem, diretamente, no valor da resistência à compressão, pois ao manter o volume de particulados constante e variar o volume de água de mistura em função das particularidades físico-químicas da adição mineral avaliada, há interferência na porosidade do sistema, o que influencia na resistência à compressão da argamassa no estado endurecido. Desta forma, os resultados de resistência à compressão obtidos para diferentes adições minerais não podem ser comparados, mas relacionados a um valor mínimo arbitrário.

A metodologia preconizada na norma não contempla qualquer restrição quanto ao volume de água de amassamento para a obtenção do índice de consistência pré-estabelecido. Assim sendo, adições minerais com elevada área específica tendem a demandar maior volume de água de mistura, penalizando, a posteriori, a resistência à compressão da argamassa.

As considerações apresentadas evidenciam que o método indireto de avaliação do potencial reativo das adições minerais não contempla ou não restringe fatores intervenientes importantes que exercem influência no IAP baseado no ensaio de ruptura à compressão. Cabe ressaltar que a metodologia normativa proposta não distingue os efeitos físico e químico das adições minerais e, portanto, o resultado experimental expressa a influência conjunta das partículas no sistema avaliado.

A Figura 4 apresenta os resultados de resistência à compressão das argamassas contendo as diferentes adições minerais estudadas. As argamassas contendo sílica de casca de arroz, sílica ativa ou metacaulim atingiram a resistência à compressão mínima de 6,0 MPa preconizada pela NBR 12.653 [16] e, portanto, com base na metodologia de avaliação da atividade pozolânica proposta pela NBR 5.751 [5], são classificadas como materiais pozolânicos passíveis de incorporação na composição de cimento Portland composto ou pozolânico. A avaliação da sílica de casca de arroz resultou em resistência à compressão média de $6,1 \mathrm{MPa}$ com desvio padrão de $0,2 \mathrm{MPa}$, valor muito próximo do mínimo estabelecido por norma, ou seja, uma pequena variação nos resultados experimentais poderia propiciar redução no valor médio de resistência à compressão, inviabilizando a sua classificação como pozolana, apesar de, conforme Hoppe Filho et al. [17], este material apresentar atividade pozolânica, mesmo em situação onde não há controle de temperatura de queima.

As argamassas com adições minerais inertes, ou seja, o fíler calcário e o fíler quartzoso, apresentaram resistência à compressão aquém do mínimo de 6,0 MPa. De fato, este comportamento previsível evidencia que não há atividade química significativa entre o hidróxido de cálcio e estes inertes estudados, por isso, são adições não pozolânicas.

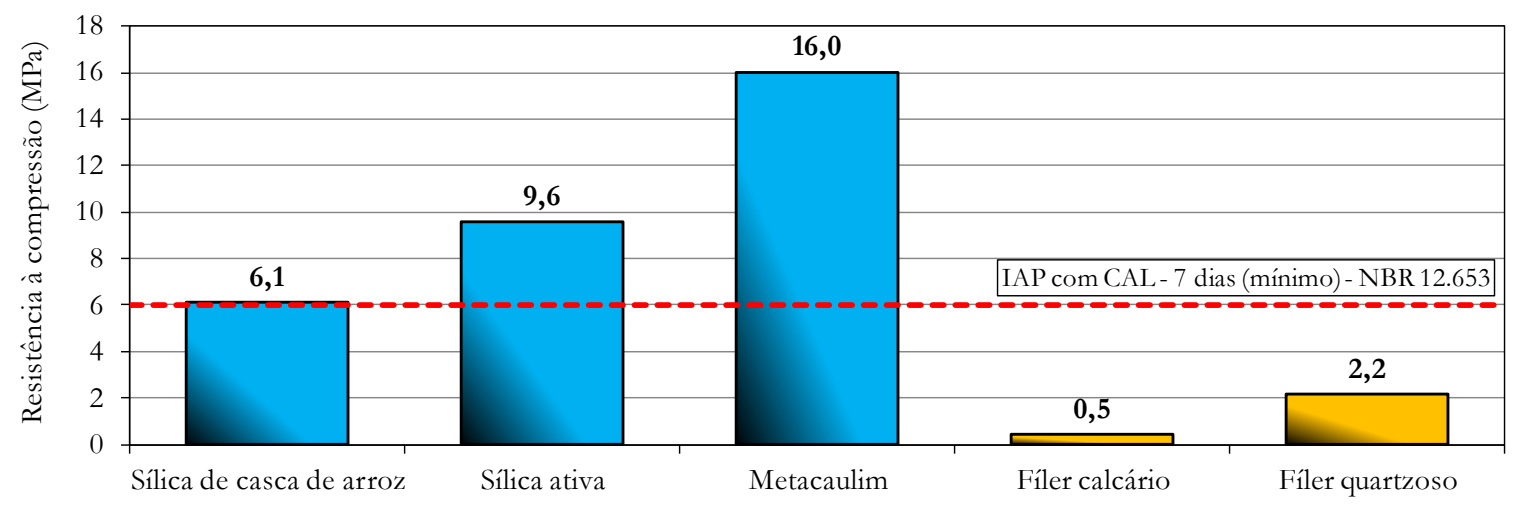

Figura 4: Resistência à compressão de argamassas com hidróxido de cálcio e diferentes adições minerais, conforme preconiza a NBR 5.751 .

A argamassa contendo metacaulim apresentou a maior resistência à compressão dentre as adições mi- 
nerais pozolânicas estudadas, atingindo 16,0 MPa aos 7 dias de idade, seguido da argamassa com sílica ativa, com resistência à compressão média de 9,6 MPa e, por fím, a argamassa com sílica de casca de arroz, comentada anteriormente. As diferentes relações água/sólidos utilizadas no amassamento das argamassas interferem na resistência à compressão e, neste sentido, a argamassa com metacaulim tende a apresentar maior resistência em comparação à argamassa contendo sílica ativa, já que demandou menor volume de água de mistura. A argamassa com sílica de casca de arroz demandou a menor quantidade de água de mistura, porém apresentou a menor resistência à compressão, indicando que a cinética de reação por atividade pozolânica, preponderante para a formação da microestrutura hidratada, exerce maior influência na carga de ruptura à compressão do que o volume de água de amassamento na idade de 7 (sete) dias.

Em suma, os resultados indicam que a sílica de casca de arroz apresenta menor cinética de reação por atividade pozolânica em comparação com a sílica ativa e o metacaulim.

\subsection{Difração de raios-X aplicada nos sistemas hidróxido de cálcio / adição mineral}

Os difratogramas das pastas contendo adição pozolânica, coletados após 7 (sete) dias de cura conforme as diretrizes da NBR 5.751 [5], são apresentados na Figura 5. Nestas pastas foram identificadas as fases cristalinas presentes nas adições minerais, os compostos hidratados formados e o halo amorfo característico de estrutura amorfa, além do consumo de portlandita por atividade pozolânica.

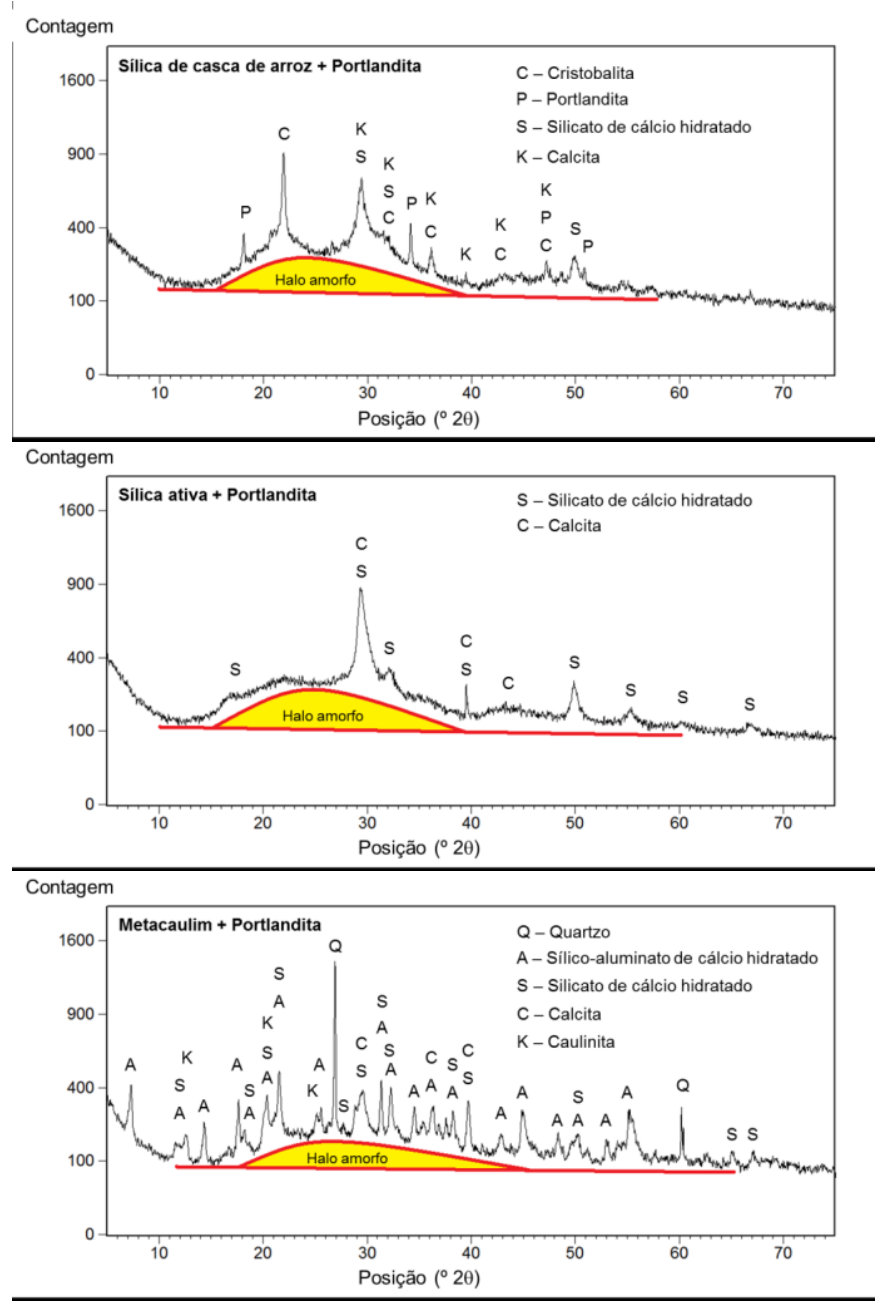

Figura 5: Difração de raios-X das pastas com adições minerais pozolânicas, após 7 (sete) dias de cura, conforme indicação da NBR 5.751 .

Na pasta com sílica de casca de arroz foram identificados picos referentes à cristobalita $\left(\mathrm{SiO}_{2}\right)$ presente na adição mineral, à portlandita e ao silicato de cálcio hidratado $(\mathrm{C}-\mathrm{S}-\mathrm{H})$. A presença de halo amorfo remanescente indica que a atividade pozolânica não consumiu totalmente a sílica amorfa e, portanto, há potencial para que reação tenha prosseguimento, desde que haja disponibilidade de cal e maior tempo de cura. A 
identificação de portlandita no meio demostra a viabilidade para haver continuidade da reação pozolânica, interrompida com o término do período de cura. Assim sendo, o período de tempo estabelecido pela norma, mesmo havendo a cura térmica $(55 \pm 2){ }^{\circ} \mathrm{C}$, não é suficiente para a sílica de casca de arroz consumir totalmente a portlandita disponível, com decorrente prejuízo no resultado de carga de ruptura à compressão.

A pasta pozolânica com sílica ativa apresenta halo amorfo, indicando haver matriz vítrea remanescente, e picos característicos do C-S-H. A portlandita foi totalmente consumida e, desta forma, sua presença não foi identificada no respectivo difratograma. O metacaulim também consumiu totalmente a portlandita disponível, formando C-S-H e sílico-aluminato de cálcio hidratado $\left(\mathrm{C}_{2} \mathrm{ASH}_{8}\right)$, sem que houvesse o esgotamento da matriz amorfa, identificada pela presença de halo amorfo no respectivo difratograma. A calcita está presente em pequenos teores em todos os difratogramas, possivelmente em decorrência da carbonatação do hidróxido de cálcio p.a. ao ser manuseado na formulação das pastas e, também, da própria carbonatação durante a cura.

A Figura 6 apresenta os difratogramas das pastas contendo adição mineral inerte. A pasta moldada com fíler calcário apresenta picos característicos de calcita $\left(\mathrm{CaCO}_{3}\right)$, dolomita $\left(\mathrm{CaCO}_{3} \cdot \mathrm{MgCO}_{3}\right)$, quartzo $\left(\mathrm{SiO}_{2}\right)$ e brucita $\left[\mathrm{Mg}(\mathrm{OH})_{2}\right]$, oriundos da adição mineral, e picos da portlandita utilizada na composição da pasta. A identificação da brucita se deve à hidratação do óxido de magnésio presente no calcário durante o período de cura. Não se verificou a formação de produto hidratado por reação química do fíler calcário, comprovando-se assim que esta adição mineral é inerte, podendo ser utilizada como material de enchimento em sistema cimentício para melhorar o empacotamento das partículas e propiciar pontos extras para a nucleação de compostos hidratados.

$\mathrm{Na}$ pasta contendo fíler quartzoso (pó de quartzo), foram identificados, após 7 (sete) dias de cura, o quartzo e a portlandita, além de indícios de compostos hidratados caracterizado pelo halo na região compreendida entre $27^{\circ}$ e $36^{\circ} 2 \theta$ (destaque na Figura 6).

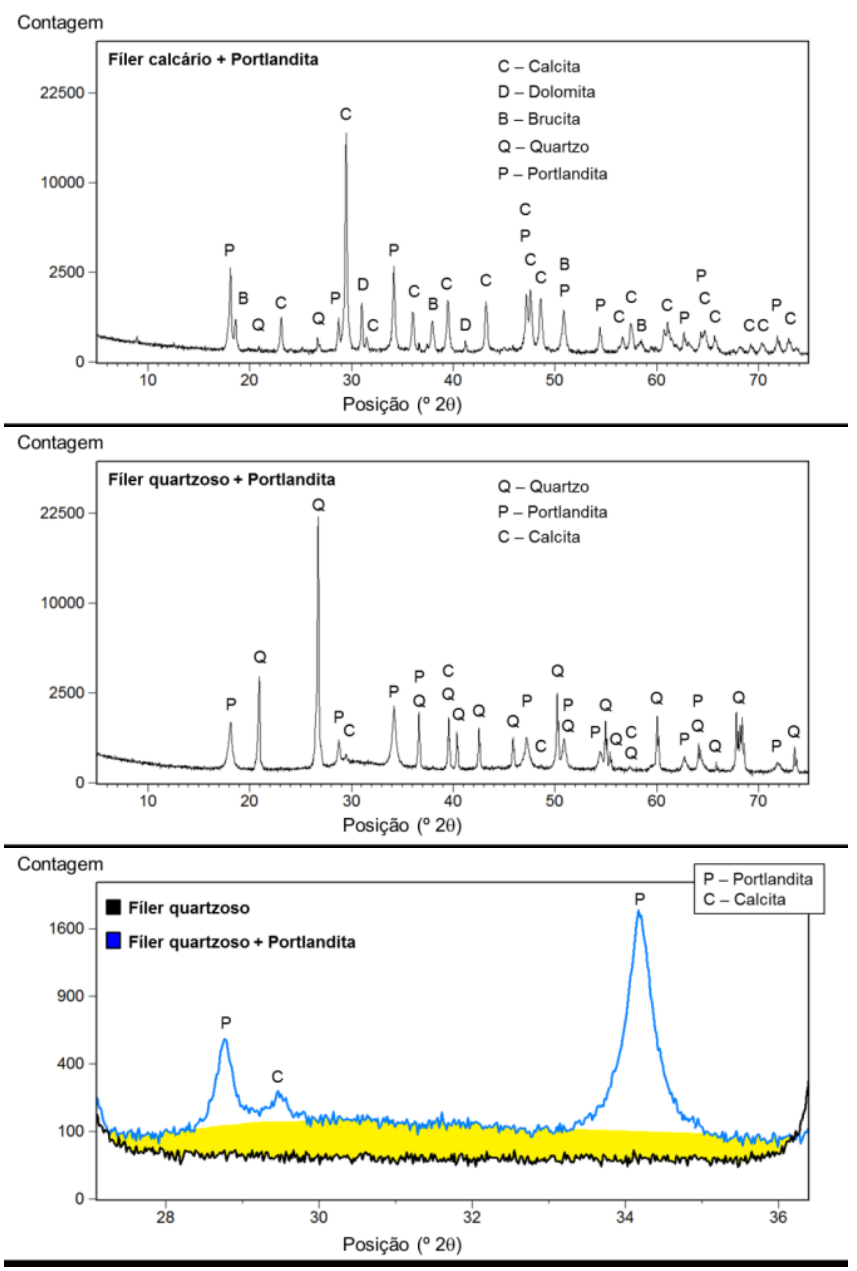

Figura 6: Difração de raios- $X$ das pastas com adições minerais inertes, após 7 (sete) dias de cura, conforme indicação da NBR 5.751 . 
Deschner et al. (2013) [10] comprovam que, a partir de $40^{\circ} \mathrm{C}$, há atividade química entre a cal e a sílica proveniente do filer quartzoso. O ensaio, conforme a norma NBR 5.751 [5], submete a pasta a uma temperatura de cura de $55^{\circ} \mathrm{C}$, o que favorece a formação de compostos hidratados que conferem resistência mecânica à argamassa. O ensaio de determinação do IAP resultou em resistência à compressão de $2,2 \mathrm{MPa}$, valor muito superior ao observado na argamassa com fíler calcário. Portanto, há que se considerar a atividade química do quartzo com a cal para justificar a capacidade portante da matriz após a cura térmica.

A análise comparativa referente ao pico de maior intensidade da portlandita $\left(34,2^{\circ} 2 \theta\right)$ é apresentado na Figura 7. Os sistemas pozolânicos contendo sílica ativa e metacaulim consomem totalmente a cal, havendo resquícios de teor remanescente na pasta com sílica de casca de arroz.

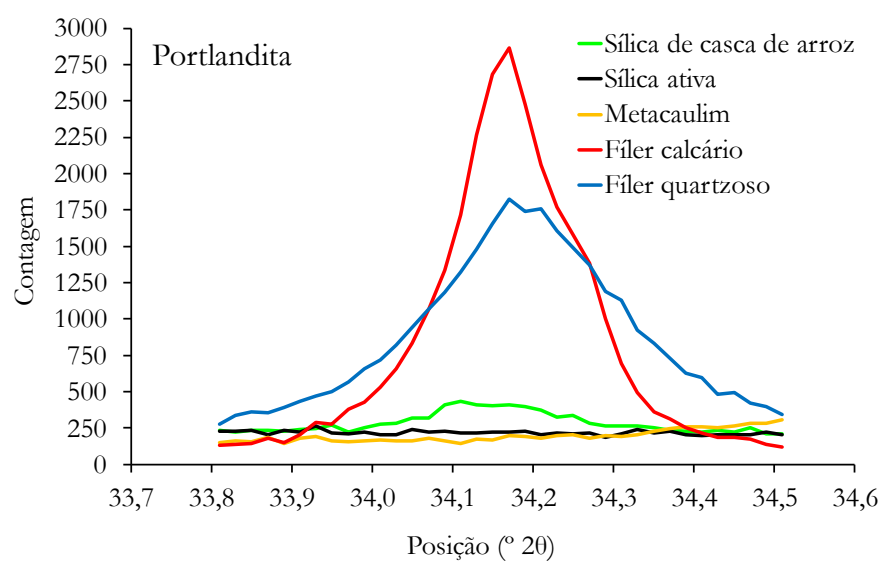

Figura 7: Teor de portlandita remanescente nos diferentes sistemas de cal com adições minerais, após 7 (sete) dias de cura, conforme indicação da NBR 5.751.

As pastas com adições minerais inertes contêm portlandita ao término do ensaio, entretanto a pasta com fíler quartzoso apresenta menor teor em comparação à pasta com fíler calcário. Tal variação caracteriza consumo de cal para formação de compostos hidratados e carbonatação da amostra.

A análise dos resultados de IAP com cal em conjunto com os difratogramas das adições pozolânicas de alta reatividade evidencia que a metodologia proposta na NBR 5.751 [5] não permite a comparação/hierarquização de adições minerais em termos de capacidade de fixação de cal haja vista o esgotamento do hidróxido de cálcio. Portanto, a metodologia normativa assume caráter unicamente classificatório, baseado na resistência à compressão. A exaustão da cal nos sistemas com sílica ativa ou metacaulim subestima o potencial reativo destas adições minerais.

\subsection{Termogravimetria aplicada nos sistemas hidróxido de cálcio / adição mineral}

A análise termogravimétrica (TG/DTG) permite quantificar, na idade preconizada na NBR 5.751 [5], o teor de hidratos formados, a portlandita consumida por atividade pozolânica e a carbonatação da amostra. A Figura 8 apresenta a análise termogravimétrica da pasta de sílica de casca de arroz. O teor de água quimicamente combinada (AQC) relacionada à formação de C-S-H é representado pela perda de massa de $8,34 \%$, ocorrida entre 35 e $380^{\circ} \mathrm{C}$. A água de composição do hidróxido de cálcio, quantificada na faixa de temperatura de 380 a $465^{\circ} \mathrm{C}$, representa $1,19 \%$ que, ao ser multiplicado por $4,11^{8}$, indica o teor remanescente de cal na amostra. $\mathrm{O}$ teor de dióxido de carbono foi quantificado pela perda de massa ocorrida entre 465 e $1.000{ }^{\circ} \mathrm{C}$ que, ao ser multiplicado por $2,27^{9}$, indica o teor de carbonato de cálcio contido na pasta.

Nas pastas estudadas, de maneira geral, a água quimicamente combinada (AQC) na formação de C-S$\mathrm{H}$ e/ou aluminatos hidratados (presente na pasta de metacaulim) volatiliza até a temperatura (aproximada) de $370{ }^{\circ} \mathrm{C}$, seguido da volatilização da água de composição do hidróxido de cálcio $\left(370^{\circ} \mathrm{C} \sim 465^{\circ} \mathrm{C}\right)$ e do dióxido de carbono decorrente da dissociação do carbonato de cálcio $\left(465^{\circ} \mathrm{C} \sim 1.000{ }^{\circ} \mathrm{C}\right)$.

\footnotetext{
${ }^{8}$ Relação da massa molecular do hidróxido de cálcio $(74,09)$ e da massa molecular da água $(18,01)$.

${ }^{9}$ Relação da massa molecular do carbonato de cálcio $(100,09)$ e da massa molecular do dióxido de carbono $(44,00)$.
} 


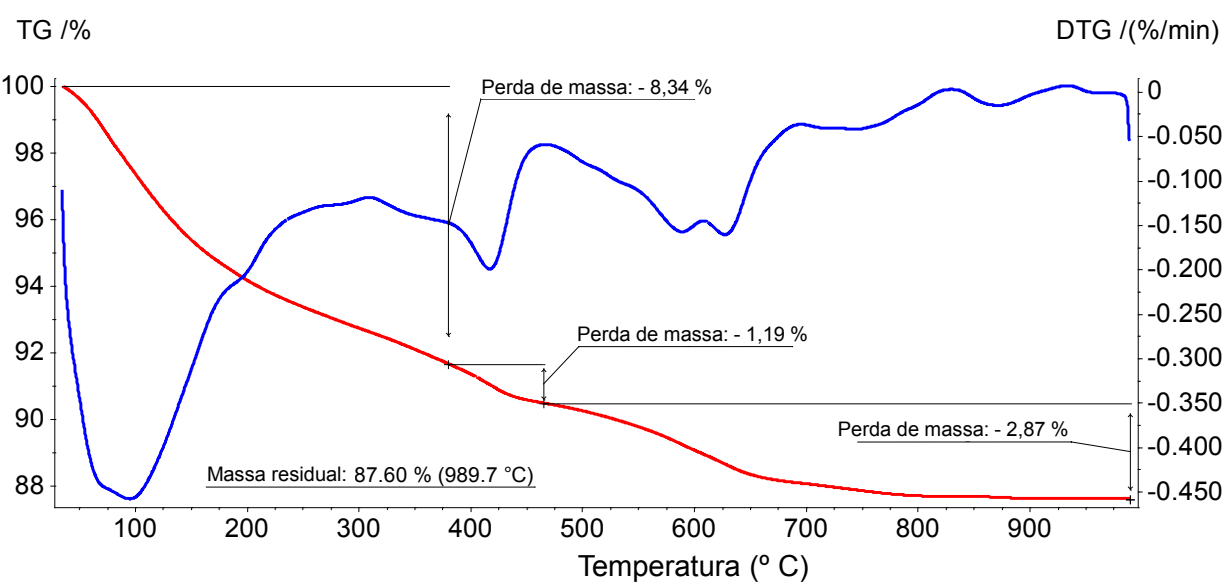

Figura 8: Análise termogravimétrica (TG/DTG) da pasta de sílica de casca de arroz e hidróxido de cálcio, após 7 (sete) dias de cura, conforme indicação da NBR 5.751.

Os resultados de perda de massa do ensaio termogravimétrico foram corrigidos para a mesma base de não voláteis, conforme recomendações de Taylor [18], para permitir a análise comparativa da atividade pozolânica das adições minerais estudadas. Para tanto, a massa residual resultante do ensaio termogravimétrico foi normalizada para $100 \%$ o que, consequentemente, causa incremento nas perdas de massa das diferentes faixas de temperatura utilizadas na interpretação das curvas TG/DTG. A tabela 4 apresenta os resultados do ensaio da pasta de sílica de casca de arroz e os correspondentes resultados corrigidos para a mesma base de não voláteis.

Tabela 4: Perdas de massa (TG/DTG) da pasta de sílica de casca de arroz e resultados na mesma base de não voláteis.

\begin{tabular}{|c|c|c|c|c|c|c|c|}
\hline \multirow[t]{2}{*}{ Pasta } & \multirow{2}{*}{$\begin{array}{c}\begin{array}{c}\text { AQC } \\
(\%)\end{array} \\
\text { C-S-H }\end{array}$} & \multicolumn{2}{|c|}{$\begin{array}{l}\text { Hidróxido de cálcio } \\
(\%)\end{array}$} & \multicolumn{2}{|c|}{$\begin{array}{c}\text { Carbonato de cálcio } \\
(\%)\end{array}$} & \multirow{2}{*}{$\begin{array}{c}\text { Massa } \\
\text { Residual } \\
(\%)\end{array}$} & \multirow{2}{*}{$\begin{array}{c}\text { Fator } \\
\text { Normalização }{ }^{1}\end{array}$} \\
\hline & & $\mathrm{H}_{2} \mathrm{O}$ & $\mathrm{Ca}(\mathrm{OH})_{2}$ & $\mathrm{CO}_{2}$ & $\mathrm{CaCO}_{3}$ & & \\
\hline \multirow{4}{*}{ Sílica de casca de arroz } & \multicolumn{7}{|c|}{ Perdas de massa do ensaio termogravimétrico (TG/DTG) } \\
\hline & 8,34 & 1,19 & 4,89 & 2,87 & 6,51 & 87,60 & 1,142 \\
\hline & \multicolumn{7}{|c|}{ Perdas de massa corrigidas para a mesma base de não voláteis } \\
\hline & 9,52 & 1,36 & 5,58 & 3,28 & 7,44 & 100,00 & --- \\
\hline
\end{tabular}

${ }^{1}$ Fator de normalização $=100 /$ massa residual da amostra

Os resultados teóricos de perdas de massa referentes à composição inicial da pasta, previamente à mistura com a água, também precisam ser corrigidos para a mesma base de não voláteis, para permitir a análise do consumo de cal por atividade pozolânica e carbonatação da amostra. A Tabela 5 apresenta as perdas de massa do hidróxido de cálcio p.a. utilizado na composição da pasta, resultados necessários para correção na mesma base de não voláteis.

Tabela 5: Perdas de massa (TG/DTG) do hidróxido de cálcio p.a. e resultados na mesma base de não voláteis.

\begin{tabular}{|c|c|c|c|c|c|c|c|}
\hline \multirow[t]{2}{*}{ Material } & \multirow{2}{*}{$\begin{array}{l}\text { Umidade } \\
\qquad(\%)\end{array}$} & \multicolumn{2}{|c|}{$\begin{array}{c}\text { Hidróxido de cálcio } \\
(\%)\end{array}$} & \multicolumn{2}{|c|}{$\begin{array}{c}\text { Carbonato de cálcio } \\
(\%)\end{array}$} & \multirow{2}{*}{$\begin{array}{c}\text { Massa } \\
\text { Residual } \\
(\%) \\
\end{array}$} & \multirow{2}{*}{$\begin{array}{c}\text { Fator } \\
\text { Normalização }^{1}\end{array}$} \\
\hline & & $\mathrm{H}_{2} \mathrm{O}$ & $\mathrm{Ca}(\mathrm{OH})_{2}$ & $\mathrm{CO}_{2}$ & $\mathrm{CaCO}_{3}$ & & \\
\hline \multirow{4}{*}{$\begin{array}{l}\text { Hidróxido de cálcio } \\
\text { p.a. }\end{array}$} & \multicolumn{7}{|c|}{ Perdas de massa do ensaio termogravimétrico (TG/DTG) } \\
\hline & 1,09 & 21,60 & 88,78 & 2,45 & 5,56 & 74,87 & 1,336 \\
\hline & \multicolumn{7}{|c|}{ Perdas de massa corrigidas para a mesma base de não voláteis } \\
\hline & 1,46 & 28,85 & 118,59 & 3,27 & 7,43 & 100,00 & --- \\
\hline
\end{tabular}

\footnotetext{
${ }^{1}$ Fator de normalização $=100 /$ massa residual da amostra
} 
A pasta de sílica de casca de arroz é composta (Tabela 3) por 104,0 gramas de hidróxido de cálcio p.a. e 196,9 gramas de adição mineral, ou seja, $34,6 \%$ e $65,4 \%$, respectivamente. De fato, esta proporção não está na mesma base de não voláteis do ensaio termogravimétrico da pasta hidratada e, portanto, os resultados não podem ser simplesmente comparados. A proporção inicial teórica, após ensaio de TG/DTG, resultaria em massa residual de $89,34 \%$, pois o hidróxido de cálcio p.a., em teor de $34,6 \%$, iria apresentar massa residual de $25,9 \%(34,6 \%$ x massa residual $(74,87 \%)$ - Tabela 5$)$ e a sílica de casca de arroz apresentaria massa residual de $63,4 \%$ (65,4\% x massa residual da sílica de casca de arroz $(97,00 \%))$. Assim sendo, a massa residual inicial teórica seria de $89,3 \%$, resultado da adição da massa residual do hidróxido de cálcio p.a. (25,9\%) e da sílica de casca de arroz $(63,4 \%)$. Desta forma, há que se normalizar a massa residual teórica de $89,3 \%$ para $100 \%$, o que resulta na proporção de $29,0 \%$ de hidróxido de cálcio calcinado e $71,0 \%$ de sílica de casca de arroz.

O teor de $29,0 \%$ de hidróxido de cálcio calcinado contém na sua composição $34,4 \%$ de hidróxido de cálcio e $2,1 \%$ de carbonato de cálcio. A obtenção destes valores decorre da proporcionalidade em relação aos resultados do hidróxido de cálcio p.a. corrigidos para $100 \%$ de massa residual (Tabela 5). Portanto, o teor de hidróxido de cálcio disponível para a atividade pozolânica da sílica de casca de arroz e a eventual carbonatação da pasta é de $34,4 \%$, enquanto o teor de carbonato de cálcio de composição do reagente de grau analítico é de $2,1 \%$.

A normalização para a mesma base de não voláteis tanto da composição inicial teórica como da pasta hidratada permite a análise comparativa dos resultados. Para a pasta de sílica de casca de arroz hidratada, o teor de AQC é de 9,6\% e o teor remanescente de portlandita é de 5,6\%. A carbonatação da amostra é estimada por meio da variação do teor de carbonato de cálcio entre as amostras, ou seja, pela subtração entre o teor determinado da pasta hidratada $(7,4 \%)$ e o teor de composição do reagente $(2,2 \%)$, o que resulta em teor de $5,3 \%$. No presente trabalho, foi considerado que a carbonatação decorre exclusivamente da ação do anidrido carbônico sobre o hidróxido de cálcio. Assim sendo, o teor de cal equivalente ao teor carbonatado foi determinado por meio da relação entre as massas moleculares do hidróxido de cálcio $(74,09)$ e o carbonato de cálcio $(100,09)$. Desta forma, a carbonatação da amostra $(5,3 \%)$ consumiu $3,9 \%$ de hidróxido de cálcio. Por fim, o teor de cal consumido por atividade pozolânica foi determinado, ao subtrair do teor de hidróxido de cálcio inicial teórico $(34,4 \%)$, o teor de cal remanescente $(5,6 \%)$ e o teor de cal consumido por carbonatação $(3,9 \%)$, o que totaliza $24,9 \%$.

A rotina apresentada para a análise dos resultados do ensaio termogravimétrico da pasta de sílica de casca de arroz foi utilizada na determinação dos resultados das demais pastas. Cabe destacar que, para o metacaulim o fíler calcário, foi considerado as perdas de massa inerentes às fases constituintes das respectivas adições minerais. No caso do metacaulim, foi considerada a perda de massa decorrente da desidroxilação da caulinita remanescente na amostra e, para o fíler calcário, foi considerada a perda de massa decorrente da dissociação do anidrido carbônico de constituição das fases carbonato contidas na amostra.

A Figura 9 apresenta o teor de AQC, o teor remanescente de portlandita e o teor de calcita formada por carbonatação dos sistemas.

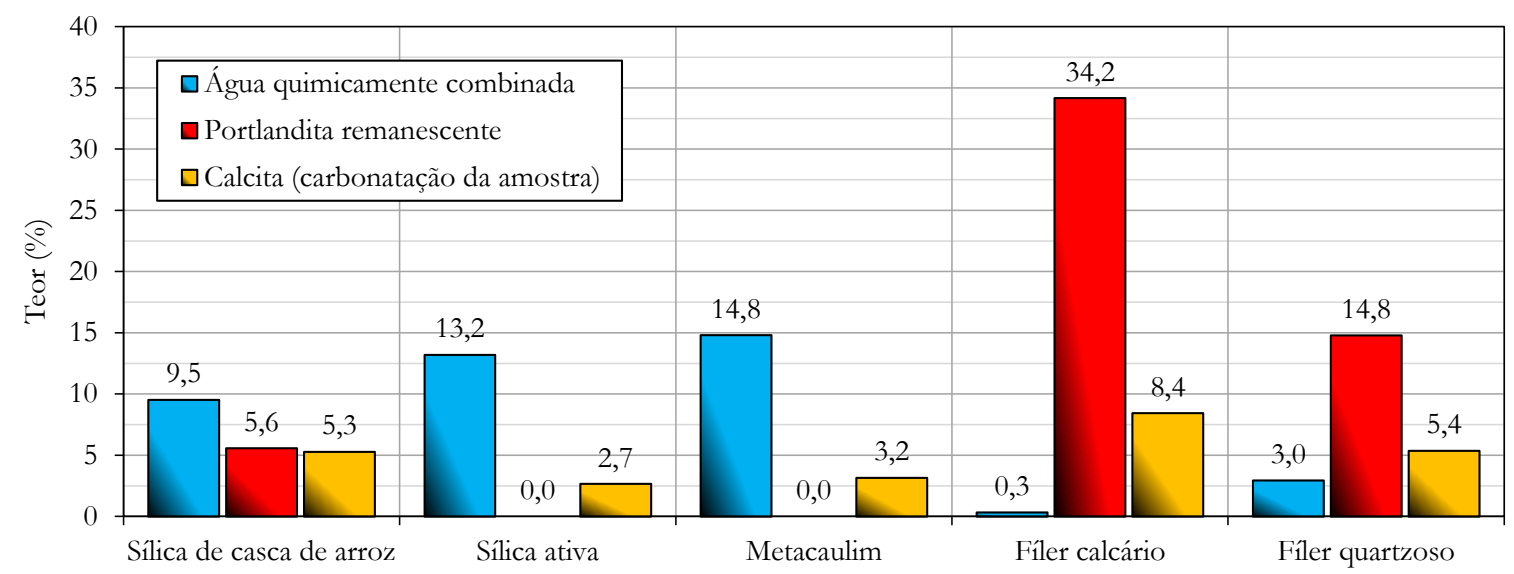

Figura 9: Teores de água quimicamente combinada como hidratos, portlandita remanescente e calcita formada por carbonatação nas diferentes pastas de cal com adições minerais, após 7 (sete) dias de cura, conforme recomendações da NBR 5.751. 
A pasta com sílica de casca de arroz possui o menor teor de AQC dentre as adições pozolânicas, sendo a única pasta a conter teor remanescente de portlandita (5,6\%). As pastas com sílica ativa ou metacaulim esgotaram a portlandita e, em consequência, formaram maior teor de compostos hidratados. Cabe salientar que a sílica ativa formou C-S-H, enquanto o metacaulim formou, além do C-S-H, o sílico-aluminato de cálcio hidratado $\left(\mathrm{C}_{2} \mathrm{ASH}_{8}\right)$, identificado no difratograma de raios-X. A presença de sílica e alumina na composição da matriz amorfa do metacaulim possibilita a formação de sílico-aluminato de cálcio hidratado, o que não ocorre com a sílica de casca de arroz e sílica ativa, compostas, predominantemente, por sílica amorfa.

O esgotamento da portlandita cessa a atividade pozolânica da adição mineral e, portanto, a proporção de mistura preconizada na norma NBR 5.751 [5] é inadequada para hierarquizar o potencial reativo da sílica ativa e do metacaulim, apesar do IAP atender o valor mínimo de 6,0 MPa estabelecido na NBR 12.653 [16].

A pasta com fíler calcário não apresentou teor de $\mathrm{AQC}$ e, portanto, não ocorreu atividade pozolânica. Já o fíler quartzoso apresentou teor de $\mathrm{AQC}$ de $3,0 \%$, com redução do teor remanescente de portlandita. Isto indica que há atividade química entre o filer quartzoso e a cal quando o sistema é submetido à temperatura de $55^{\circ} \mathrm{C}$, o que está de acordo com a pesquisa de Deschner et al. [10]. A formação de hidratos justifica a resistência à compressão de 2,2 MPa obtida no ensaio de determinação do índice de atividade pozolânica com cal.

A carbonatação foi observada em todos os sistemas durante o período de cura, sendo mais evidente nas pastas com adições minerais inertes, justamente as mais abundantes em portlandita durante todo o período de cura. Portanto, parte da cal é consumida pela ação do anidrido carbônico, o que chegou a reduzir, em média, $9 \%$ a disponibilidade de portlandita para a atividade pozolânica nos sistemas com adições minerais ativas.

A Figura 10 apresenta o teor inicial de portlandita presente nos sistemas, bem como o teor remanescente de cal, o teor de cal consumido por atividade pozolânica e, por fim, o teor de portlandita que sofreu carbonatação, todos valores expressos na base de não voláteis, após 7 (sete) dias de cura, conforme indicação da NBR $5.751[5]$.

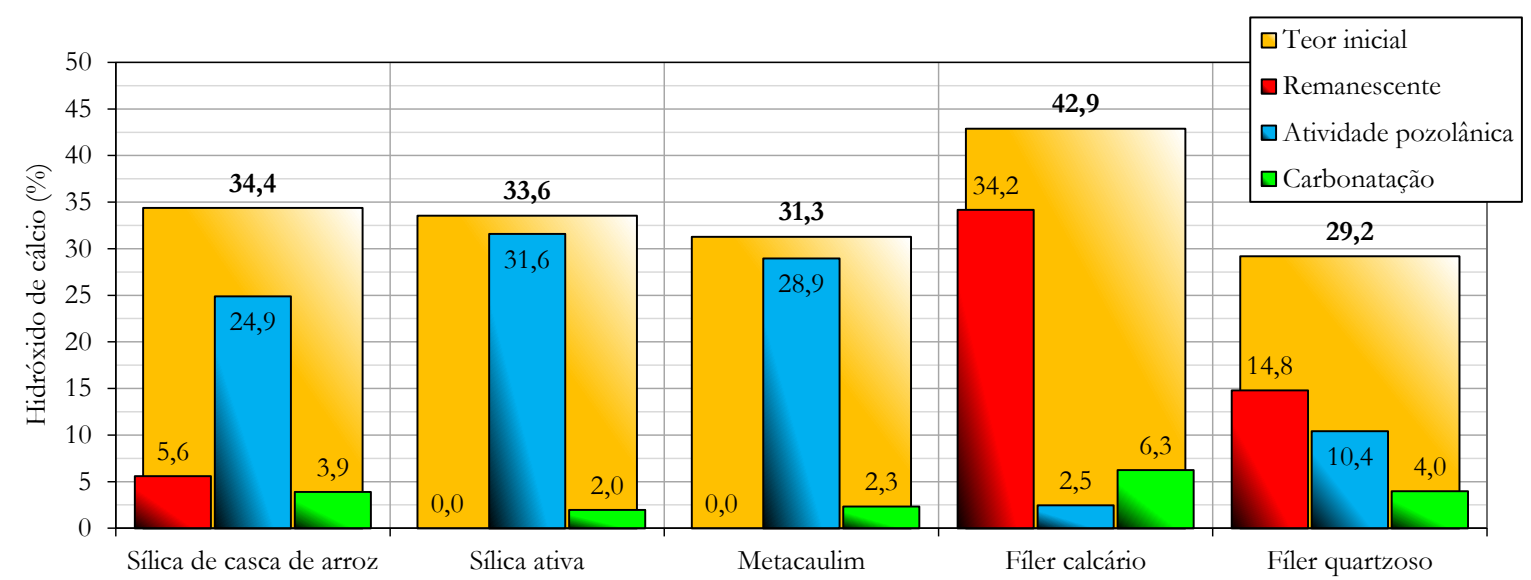

Figura 10: Teores de portlandita disponíveis nos sistemas cal / adição mineral, teores remanescentes de cal, teores de portlandita fixados por atividade pozolânica e teores de portlandita consumidos por carbonatação, após 7 (sete) dias de cura, conforme indicação da NBR 5.751.

A pasta com sílica de casca de arroz dispõe de portlandita residual ao término do ensaio e, portanto, a pozolanicidade desta adição pode ser avaliada segundo as condições de ensaio preconizadas na norma NBR 5.751 [5]. O consumo de cal calculado neste ensaio foi de $351 \mathrm{mg} \mathrm{Ca}(\mathrm{OH})_{2} /$ grama de sílica de casca de arroz. As demais pozolanas de alta reatividade apresentaram consumo de $441 \mathrm{mg} \mathrm{Ca}(\mathrm{OH})_{2}$ / grama de sílica ativa e $393 \mathrm{mg} \mathrm{Ca}(\mathrm{OH})_{2}$ / grama de metacaulim, restringidos pelo esgotamento de cal nos respectivos sistemas.

Os teores de cal fixados pela sílica de casca de arroz e pelo metacaulim apresentam pequena variação enquanto os IAP's são bastante distintos, ou seja, resistência à compressão de 6,1 MPa para a sílica de casca de arroz e 16,0 MPa para o metacaulim. De fato, a sílica de casca de arroz apresenta reatividade similar ao metacaulim, entretanto, o IAP situou-se no limiar para a classificação como adição mineral pozolânica conforme o limite estabelecido pela norma NBR 12.653 [16]. Assim sendo, há que se considerar ressalvas quando da determinação da pozolanicidade de adição mineral ao se empregar a metodologia proposta na NBR $5.751[5]$. 
O fíler calcário não consome cal em virtude do seu caráter inerte. A pasta com fíler quartzoso fixou um teor de $10,1 \%$ de portlandita. A proporção de mistura desta pasta, na base de não voláteis, é de $24,4 \%$ de hidróxido de cálcio e $75,6 \%$ de adição mineral, o que resulta em um consumo de $138 \mathrm{mg} \mathrm{Ca}(\mathrm{OH})_{2} /$ grama de fíler quartzoso.

\subsection{Ensaio Chapelle modificado}

O método direto de determinação do teor de cal fixado por atividade pozolânica otimiza a interação da adição mineral com o hidróxido de cálcio em virtude da realização do ensaio em solução, sob agitação, pois a reação é acelerada pela elevada temperatura $\left(90^{\circ} \mathrm{C} \pm 5^{\circ} \mathrm{C}\right)$. Assim sendo, há potencialização da atividade pozolânica e o consequente consumo de cal passa a ser um indicativo do potencial reativo máximo da adição mineral. A Figura 11 apresenta os teores de cal fixados pelas adições minerais conforme as diretrizes de ensaio da norma NBR 15.895 [6].

A sílica ativa apresentou a maior reatividade entre as pozolanas, com consumo de $1.542 \mathrm{mg}$ $\mathrm{Ca}(\mathrm{OH})_{2} / \mathrm{g}$ de adição, seguida da sílica de casca de arroz e, por fim, do metacaulim. Os valores de consumo de cal são superiores ao consumo de $330 \mathrm{mg} \mathrm{CaO} / \mathrm{g}$ de adição (equivalente a $436 \mathrm{mg} \mathrm{Ca}(\mathrm{OH})_{2} / \mathrm{g}$ de adição), valor mínimo estabelecido por Raverdy et al. [19] para classificação da adição mineral como material pozolânico.

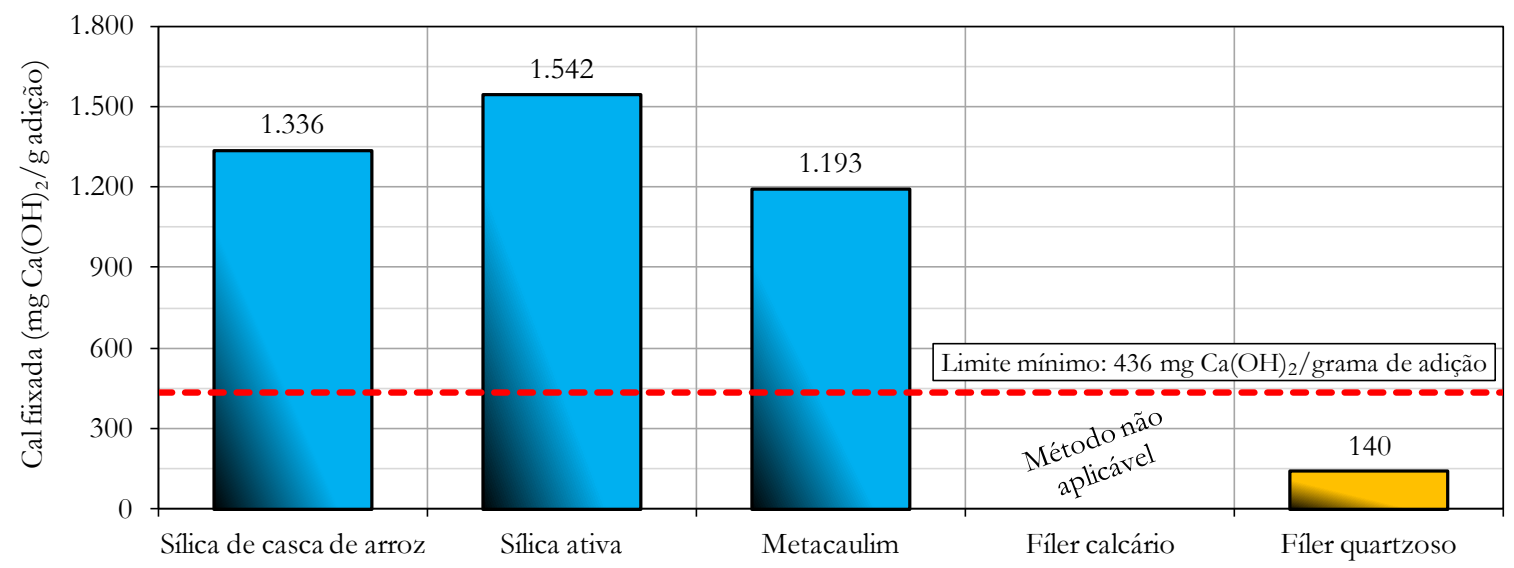

Figura 11: Teores de hidróxido de cálcio fixados, por atividade pozolânica, conforme o método Chapelle modificado preconizado na norma NBR 15.895 .

O fíler quartzoso, com consumo de cal de $140 \mathrm{mg} \mathrm{Ca}(\mathrm{OH})_{2} / \mathrm{g}$ de adição, não pode ser classificado como pozolana, embora ocorra alguma interação química entre o quartzo e a cal, coerente com a resistência à compressão do sistema, avaliada no método indireto normalizado. Cabe enfatizar que o consumo de cal do fíler quartzoso, avaliado no estudo em pasta por termogravimetria, resultou em $138 \mathrm{mg} \mathrm{Ca}(\mathrm{OH})_{2} / g$ de adição, valor similar ao determinado pelo ensaio Chapelle modificado.

A avaliação da atividade pozolânica de adições minerais de alta reatividade por meio do ensaio Chapelle modificado, realizada por Quarcioni et al. [20], resultou, para a cinza de casca de arroz, em teores de cal fixado entre 559 e $1.080 \mathrm{mg} \mathrm{CaO} /$ grama, o que equivale a 739 e $1.427 \mathrm{mg} \mathrm{Ca}(\mathrm{OH})_{2} /$ grama. Para a sílica ativa, os resultados situaram-se entre 967 e $1.153 \mathrm{mg} \mathrm{CaO} /$ grama, equivalente a 1.278 e $1.524 \mathrm{mg} \mathrm{Ca}(\mathrm{OH})_{2} / \mathrm{grama}$, respectivamente. Por fim, para o metacaulim, os teores de cal fixado variaram de 752 a $1.015 \mathrm{mg} \mathrm{CaO} / \mathrm{grama}$, ou seja, entre 994 e $1.341 \mathrm{mg} \mathrm{Ca}(\mathrm{OH})_{2}$ /grama. Os teores de cal fixados pelas adições minerais utilizadas neste trabalho estão de acordo com os valores apresentados por Quarcioni et al. [20], o que evidencia a alta reatividade das amostras.

Medina [21], ao avaliar a capacidade de fixação de cal de uma amostra de metacaulim, com área específica BET de $32,7 \mathrm{~m}^{2} / \mathrm{g}$ e diâmetro médio das partículas de $9,05 \mu \mathrm{m}$, obteve o consumo de $999 \mathrm{mg} \mathrm{Ca}(\mathrm{OH})_{2} /$ grama. $\mathrm{O}$ teor de cal fixado foi inferior ao determinado na amostra deste estudo, apesar desta apresentar menor área específica BET $\left(23,26 \mathrm{~m}^{2} / \mathrm{g}\right)$ e maior diâmetro médio de partículas $(15,92 \mu \mathrm{m})$. Tal comportamento indica que a capacidade de fixar cal não depende única e exclusivamente das características físicas da pozolana, ou seja, a composição química e o teor e constituição da fração amorfa são, também, relevantes para a atividade pozolânica. 
O consumo de cal determinado pelo ensaio Chapelle modificado resulta, com base na sílica ativa, em uma proporção de mistura de 1 (uma) unidade volumétrica de hidróxido de cálcio e uma quantidade de adição mineral que corresponde a $0,7(70 \%)$ do volume de hidróxido de cálcio. Esta proporção difere consideravelmente daquela proposta na NBR 5.751 [5], onde o volume de adição mineral deve ser o dobro do volume de hidróxido de cálcio.

O esgotamento da portlandita nos sistemas de cal com sílica ativa ou metacaulim indica que a proporção volumétrica estabelecida na norma NBR 5.751 [5] não é adequada para a determinação da atividade pozolânica das adições minerais de alta reatividade. Portanto, há que se reduzir a proporção de mistura volumétrica, de forma a assegurar portlandita remanescente no sistema ao término do período de cura. Como o estudo em pasta/argamassa não apresenta as condições maximizadas semelhantes ao ensaio Chapelle modificado (ensaio sob agitação contínua e elevada temperatura de cura), a redução na proporção de mistura não, obrigatoriamente, deve seguir a relação volumétrica estabelecida a partir do resultado do ensaio direto com a sílica ativa, embora tal relação seria desejável para assegurar a reserva alcalina ao término do ensaio.

O estudo da atividade pozolânica das adições minerais com cimento Portland, que será tratado na segunda parte deste trabalho, contempla uma proporção volumétrica de hidróxido de cálcio e pozolana intermediária às aqui abrangidas. A análise desta nova proporção poderá subsidiar a indicação de uma relação volumétrica mais adequada para a determinação da atividade pozolânica com cal destinada ao estudo de adições minerais de alta reatividade.

\section{CONSIDERAÇÕES FINAIS}

A análise acerca da pozolanicidade de adições minerais, considerando os dados obtidos da difratometria de raios-X e da termogravimetria como complementares para a avaliação da atividade pozolânica de adições minerais de alta reatividade por meio do método estabelecido pela norma NBR 5.751 [5], além do ensaio Chapelle modificado, conforme a NBR 15.895 [6], permite as seguintes considerações:

- A determinação do índice de atividade pozolânica (IAP) com cal, conforme a NBR 5.751 [5], atribui pozolanicidade às adições minerais de alta reatividade, mesmo para a argamassa de sílica de casca de arroz que apresentou resistência à compressão ligeiramente superior ao valor mínimo de 6,0 $\mathrm{MPa}$, estabelecido como parâmetro de classificação pela norma NBR 12.653 [16].

- O fíler quartzoso, apesar de não ser classificado como pozolana, interagiu quimicamente com a cal, promovendo a resistência à compressão de $2,2 \mathrm{MPa}$ na argamassa, valor este superior ao observado na argamassa com fíler calcário, cujo material é classificado como inerte.

- A difratometria de raios-X indicou presença de fase amorfa remanescente nas adições minerais pozolânicas ao término do ensaio, dado ao esgotamento da cal nos sistemas, exceto na pasta com sílica de casca de arroz. As pastas com sílica de casca de arroz ou sílica ativa, após a interação com a cal, formam sílicato de cálcio hidratado (C-S-H), enquanto a pasta com metacaulim forma, além do C-S-H, o sílicoaluminato de cálcio hidratado. Na pasta com fíler calcário foram identificados os picos referentes aos constituintes da adição mineral (calcita, dolomita e quartzo), portlandita e brucita, esta decorrente da hidratação do óxido de magnésio originário do calcário. O difratograma da pasta com fíler quartzoso apresentou redução no teor de portlandita em comparação (semi-quantitativa / qualitativa) à pasta com fíler calcário, além de indícios de compostos hidratados, identificados por meio do tênue halo na região compreendida entre $27^{\circ}$ e $36^{\circ}$ $2 \theta$.

- A análise térmica corrobora a difratometria de raios-X no que tange ao esgotamento da cal nas pastas com sílica ativa e metacaulim, com teor remanescente de portlandita na pasta com sílica de casca de arroz. A análise da curva TG/DTG da pasta de cal e fíler quartzoso indica consumo de portlandita de $138 \mathrm{mg} \mathrm{Ca}(\mathrm{OH})_{2} /$ grama de adição e, consequentemente, formação de compostos hidratados, quantificados por meio da água quimicamente combinada.

- Os valores de área específica BET da sílica de casca de arroz $\left(14,69 \mathrm{~m}^{2} / \mathrm{g}\right)$ e da sílica ativa $\left(20,24 \mathrm{~m}^{2} / \mathrm{g}\right)$ estão diretamente relacionados ao consumo de cal e, consequentemente, ao teor de água quimicamente combinada. $\mathrm{O}$ teor remanescente de cal no sistema com sílica de casca de arroz poderá se esgotar se esta adição mineral apresentar maior área específica BET.

- O teor de água quimicamente combinada nos sistemas compostos por adições minerais pozolânicas está diretamente relacionado com o resultado do IAP, mesmo com a ocorrência de diferentes compostos hidratados.

- Os resultados do ensaio Chapelle modificado indicam que a sílica de casca de arroz, a sílica ativa e o metacaulim fixam valores superiores a $1.100 \mathrm{mg} \mathrm{Ca}(\mathrm{OH})_{2} /$ grama de adição mineral, o que os qualifica como 
pozolanas de alta reatividade. A sílica de casca de arroz é capaz de fixar maior quantidade de cal que o metacaulim, entretanto, o IAP indica, por meio da hierarquização indireta (resistência à compressão) um comportamento oposto com a possibilidade, inclusive, de não classificá-la como material pozolânico. Assim sendo, a determinação da atividade pozolânica com cal (IAP) deve ser utilizada com ressalvas.

- A determinação do índice de atividade pozolânica (IAP) com cal, conforme estabelece a NBR 5.751 [5], não é adequada para a hierarquização de adições minerais pozolânicas de alta reatividade, haja vista a probabilidade de esgotamento da cal durante o período de ensaio. O esgotamento da portlandita cessa a atividade pozolânica e, consequentemente, subestima-se o potencial reativo da adição mineral, apesar de atender ao critério estabelecido na NBR 12.653 [16] para classificação como pozolana.

- A proporção volumétrica de materiais particulados indicada na norma NBR 5.751 [5] deve ser alterada, quando da caracterização de adições minerais de alta reatividade, para reduzir a relação adição mine$\mathrm{ral} /$ portlandita, de forma a manter disponível teor residual de cal ao término do ensaio.

- A disponibilidade de portlandita ao término do ensaio é imprescindível para que outros fatores intervenientes possam ser abordados em previsão de implantação de novas melhorias na metodologia de avaliação do IAP com cal como, por exemplo, a influência da área específica das adições minerais, a cinética de reação em função da composição mineralógica do material caracterizado e a utilização de aditivo dispersante para manter constante a relação água/ligantes das argamassas.

\section{AGRADECIMENTOS}

Os autores agradecem o apoio do laboratório multiusuário da Universidade Estadual de Ponta Grossa (CLABMU), da Universidade Federal do Oeste da Bahia e da Universidade Federal do Paraná.

\section{BIBLIOGRAFIA}

[1] LOTHENBACH, B., SCRIVENER, K., HOOTON, R. D., "Supplementary cementitious materials", $\mathrm{Ce}$ ment and Concrete Research, v. 41, n. 12, pp. 1244-1256, December 2011.

[2] ANTONI, M., ROSSEN, J., MARTINERA, F., et al., "Cement substitution by a combination of metakaolin and limestone", Cement and Concrete Research, v. 42, n. 12, pp. 1579-1589, December 2012.

[3] SINDICATO NACIONAL DA INDÚSTRIA DO CIMENTO - SNIC. Relatório anual 2013, http://www.snic.org.br/. Acessado em junho de 2016.

[4] ASSOCIAÇÃO BRASILEIRA DE NORMAS TÉCNICAS. Materiais pozolânicos - Determinação de atividade pozolânica com cimento Portland - Índice de atividade pozolânica com cimento. NBR 5.752. Rio de Janeiro, 2012.

[5] ASSOCIAÇÃO BRASILEIRA DE NORMAS TÉCNICAS. Materiais pozolânicos - Determinação de atividade pozolânica - Índice de atividade pozolânica com cal. NBR 5.751. Rio de Janeiro, 2012.

[6] ASSOCIAÇÃO BRASILEIRA DE NORMAS TÉCNICAS. Materiais pozolânicos - Determinação do teor de hidróxido de cálcio fixado - Método Chapelle modificado. NBR 15.895. Rio de Janeiro, 2010.

[7] GAVA, G. P.; PRUDÊNCIO JR., L. R. "Pozzolanic activity tests as a measure of pozzolans' performance. Part 1”, Magazine of Concrete Research, v. 59, n. 10, pp. 729-734, December 2007.

[8] GAVA, G. P.; PRUDÊNCIO JR., L. R. "Pozzolanic activity tests as a measure of pozzolans' performance. Part 2", Magazine of Concrete Research, v. 59, n. 10, pp. 735-741, December 2007.

[9] DONATELLO, S., TYER, M., CHEESEMAN, C. R. "Comparison of test methods to assess pozzolanic activity", Cement and Concrete Composites, v. 32, n. 2, pp. 121-127, February 2010.

[10] DESCHNER, F., LOTHENBACH, B., WINNEFELD, F., et al.," Effect of temperature on the hydration of Portland cement blended with siliceous fly ash", Cement and Concrete Research, v. 52, pp. 169-181, October 2013.

[11] AGARWAL, S. K. "Pozzolanic activity of various siliceous materials", Cement and Concrete Research, v. 36, n. 9, pp. 1735-1739, September 2006.

[12] CORDEIRO, G. C., TOLEDO FILHO, R. D., TAVARES, L. M., et al., "Influence of particle size and specific surface area on the pozzolanic activity of residual rice husk ash", Cement and Concrete Composites, v. 33, n. 5, pp. 529-534, May 2011.

[13] ZERBINO, R., GIACCIO, G., ISAIA, G. C. "Concrete incorporating rice-husk ash without processing", Construction and Building Materials, v. 25, n. 1, pp. 371-378, January 2011. 
[14] ZERBINO, R., GIACCIO, BATIC, O. R., et al., "Alkali-silica reaction in mortars and concretes incorporating natural rice husk ash", Construction and Building Materials, v. 36, pp. 796-806, November 2012.

[15] QUARCIONI, V. A., Influência da cal hidratada nas idades iniciais da hidratação do cimento Portland - estudo em pasta, Tese de D.Sc., Universidade de São Paulo, USP, São Paulo, Brasil, 2008.

[16] ASSOCIAÇÃO BRASILEIRA DE NORMAS TÉCNICAS. Materiais pozolânicos — Requisitos. NBR 12.653. Rio de Janeiro, 2012.

[17] HOPPE FILHO, J., TANAKA, S. I., GARCEZ, M. R., et al., "Atividade pozolânica de cinza de casca de arroz residual com diferentes tamanhos de partículas", In: $54^{\circ}$ Congresso Brasileiro do Concreto - Ibracon, Maceió, Alagoas, 2012.

[18] TAYLOR, H. F. W. Cement chemistry. London, Thomas Telford Publishing, 1997.

[19] RAVERDY M., BRIVOT F., PAILLERE A.M., DRON, R. "Appreciation de I'activite pouzzolanique des constituants secondaires", In: 7th Int. Congr. Chem. Cem. Paris, 1980.

[20] QUARCiOni, V. A., CHOTOLI, F. F., COELhO; A. C. V., et al., "Indirect and direct Chapelle's methods for the determination of lime consumption in pozzolanic materials", Revista Ibracon de Estruturas e Materiais, v. 8, n. 1, pp. 1-7, February 2015.

[21] MEDINA, E. A. Pozolanicidade do metacaulim em sistemas binários com cimento Portland e hidróxido de cálcio, Dissertação de M.Sc., Universidade de São Paulo, USP, São Paulo, Brasil, 2011. 